\title{
A New Approch for Catalyst Optimization: Host/Guest Complexes of Chiral Bisphosphine Bearing Imidazolidinone and Their Application in Rh-Catalyzed Asymmetric Hydrogenation ${ }^{\dagger}$
}

\author{
Jung Hwan Park, Hyunik Shin, ${ }^{\ddagger}$ Doo Han Park, ${ }^{\S}$ and Sang-gi Lee ${ }^{*}$ \\ Department of Chemistry and Nano Science (BK21), Ewha Womans University, Seoul 120-750, Korea \\ *E-mail: sanggi@ewha.ac.kr \\ $\ddagger$ Chemical Development Division, LG Life Sciences, Ltd./R\&D, Daejeon 305-380, Korea \\ ${ }^{\S}$ Department of Chemistry, Sahmyook University, Seoul 139-742, Korea \\ Received October 20, 2009, Accepted October 28, 2009
}

\begin{abstract}
As a new strategy for the optimization of a chiral catalyst, the catalytic activity of the host-guest complexes of chiral bisphosphine bearing imidazolidinone was investigated in Rh-catalyzed asymmetric hydrogenation of enamide. Marginal enhancement in enantioselectivity was observed and the nature of interaction between host-guest was experimentally elucidated.
\end{abstract}

Key Words: Chiral catalyst, Catalyst optimization, Host/guest

\section{Introduction}

Metal catalyzed asymmetric catalysis is one of the important synthetic methods for the preparation of optically active compounds, for which more than thousands of chiral catalysts themselves have been designed during last 20 years mostly on the basis of the intuition of the chemists. ${ }^{1}$ Recently, a new strategy to the development of chiral catalysts has been emerged. The use of a chiral ligand in combination with an achiral- or a meso ligand is employed to generate new chiral catalysts, in which one of the possible diastereomeric metal complexes is formed preferentially via coordination of the exogenous chiral source to the metal. ${ }^{2}$ An advantage of this approach is easiness of catalyst optimization using readily available achiral or meso ligands, thus minimizing an arduous task for the synthesis of enantiopure ligands.

In this paper, we present a new way for fine-tuning chiral catalysts using hydrogen-bonded host-guest concept. In nature, the non-covalent intermolecular interactions such as $\pi-\pi$ interaction and hydrogen-bonding played an important role to alter molecular conformation and consequently regulate dynamic functions such as molecular recognition and catalytic activity in biological system. Inspired by theses natural system, Roelfes and co-workers utilized the non-covalent interactions between DNA and organic-metal complex to generate the DNA-based chiral catalysts, in which the chiral information of the DNA could be transferred to the reaction site of the achiral metal complex through the non-covalent interactions between DNA and achiral metal complex. ${ }^{3}$ In present work, we envisioned that the strong intermolecular hydrogen-bonding interactions between achiral host and chiral ligand could influence on the conformation of metal-complex of the guest chiral ligand. In this manner, the ligand conformation in reaction site could easily be tuned by the non-covalent intermolecular interactions

${ }^{\dagger}$ This paper is dedicated to Professor Sunggak Kim on the occasion of his honorable retirement. between achiral host and chiral metal-complex, where the catalytic activity of a chiral ligand-metal complex could be optimized by varying achiral host.

To demonstrate the $\mathrm{H} / \mathrm{G}$-based catalyst optimization concept, we chose the chiral bisphosphine ligand bearing imidazolidin2-one (abbreviated as H-BDPMI) ${ }^{4}$ as a chiral guest which is one of the well-known moieties as hydrogen-bonding donor/ receptor. ${ }^{5}$ The five different achiral hosts 1-5 were easily synthesized from commercially available amines and isophthaloyl dichloride, which were frequently used as a hydrogen-bonding donors/receptors. ${ }^{6}$ The Rh-catalyzed asymmetric hydrogenation of an enamide was carried out as a model catalytic reaction. The $\mathrm{Rh}$-complex was prepared in situ by mixing equivalent amount of $\mathrm{H}-\mathrm{BDPMI}$ and $\left[\mathrm{Rh}(\mathrm{COD})_{2}\right] \mathrm{BF}_{4}$ in $\mathrm{CH}_{2} \mathrm{Cl}_{2}$ for $1 \mathrm{~h}$ at room temperature under argon atmosphere. To the

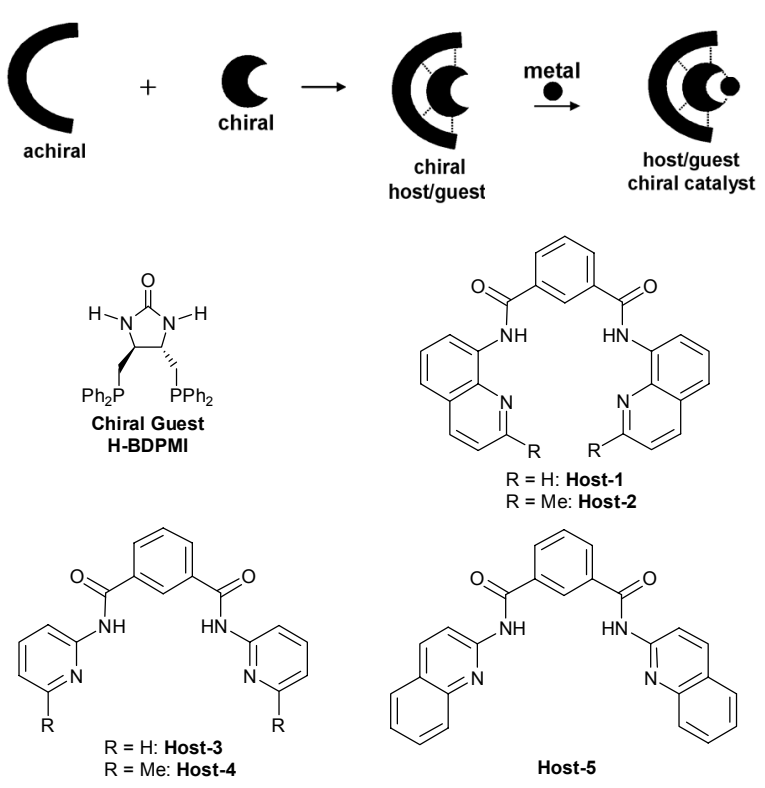

Figure 1. Schematic presentation of H/G-based chiral catalyst, and the structures of chiral bisphosphine guest and achiral hosts. 
mixture was added host, and the mixture was stirred for $2 \mathrm{~h}$. The hydrogenation was conducted for $12 \mathrm{~h}$ at $1 \mathrm{~atm}$ of hydrogen pressure. As shown in Table 1, the enantioselectivities obtained with all of the H/G-based chiral catalysts $\mathbf{H}-\mathbf{1} \sim \mathbf{5} / \mathbf{G}$ (entries $2 \sim 6)$ were higher $(+1.7 \sim+6.1 \%$ ee $)$ than that obtained with H-BDPMI catalyst ( $83.8 \%$ ee, entry 1$)$. The same results were obtained with the catalyst prepared different way, i.e. $\mathrm{H} / \mathrm{G}$ complex was prepared first by mixing with H-BDPMI and host, then $\mathrm{Rh}(\mathrm{COD})_{2} \mathrm{BF}_{4}$ was added to form a $\mathrm{Rh}$-complex. However, it was found that the catalyst, which was prepared by mixing the host and $\mathrm{Rh}(\mathrm{COD})_{2} \mathrm{BF}_{4}$ first followed by the addition of chiral bisphosphine, did not showed any catalytic activity. These results suggest that the observed catalytic activity come from the Rh-complex of the chiral bisphosphine ligand, and moreover, the host or guest ligand chelated with Rh-metal did not exchanged each other. We next varied the ratio of host/guest to see whether the catalysis is derived from the depicted 1:1 complex of achiral host and chiral guest or not. Therefore, at higher host:H-BDPMI-Rh complex ratios, the amounts of unbound H-BDPMI-Rh complex in solution will be negligible and the ee obtained should be derived from 1:1 complex of achiral host and chiral guest. However, the ee values were not significantly increased as increasing the host concentration, which suggested that the host-guest binding is saturated. In addition, when the hydrogenations were carried out in a protic solvent, $\mathrm{MeOH}$, in which host-guest complexation is prohibited by competitive H-bond by solvent, the Rhcomplex of $\mathbf{H - 5} / \mathbf{G}$ and Rh-H-BDPMI complex exhibited the same enantioselectivity (73.6\%ee) (compare entries 7 and 8), but with lowered conversion with $\mathbf{H - 5 / G}$ compare to H-BDPMI Combining all the observation into account, it is reasonable to conclude that the formation of host-guest complex increased the enantioselectivity $+1.7 \sim+6.1 \%$ ee (entries $2-6$, Table 1 ).

Table 1. Rh-Catalyzed asymmetric hydrogenation of N-acetylphenylethenamine using $\mathrm{H} / \mathrm{G}$-complex ligands prepared from $\mathbf{H}-$ BDPMI and host 1-5
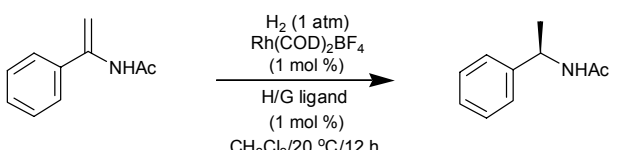

$\mathrm{CH}_{2} \mathrm{Cl}_{2} / 20^{\circ} \mathrm{C} / 12 \mathrm{~h}$

\begin{tabular}{ccccc}
\hline entry & ligand & Conv. $(\%)^{b}$ & \%ee $^{c}$ & $\Delta \% \mathrm{ee}$ \\
\hline 1 & H-BDPMI & 100 & 83.8 & - \\
2 & H-1/G & 100 & 85.8 & +2.3 \\
3 & H-2/G & 100 & $86.2(87.2,87.4,87.2)^{d}$ & $+2.7 \sim+3.6$ \\
4 & H-3/G & 15 & 89.6 & +6.1 \\
$5^{d}$ & H-4/G & 100 & 85.2 & +1.7 \\
6 & H-5/G & 100 & $86.0(86.6,86.8,86.6)^{d}$ & $+2.5 \sim+3.0$ \\
$7^{e}$ & H-BDPMI & 100 & 73.6 & - \\
$8^{e}$ & H-5/G & 14 & 73.6 & -
\end{tabular}

${ }^{a}$ The catalyst was made in situ by mixing $\mathrm{Rh}(\mathrm{COD})_{2} \mathrm{BF}_{4}(0.062 \mathrm{mmol})$ with H-BDPMI $(0.062 \mathrm{mmol})$ followed by addition of equimolar amount of host $(0.062 \mathrm{mmol})$ in $\mathrm{CH}_{2} \mathrm{Cl}_{2}(2 \mathrm{~mL})$. After addition of substrate $(0.62$ $\mathrm{mmol}, 0.31 \mathrm{M})$, the mixture was subjected into $1 \mathrm{~atm}$ of hydrogen atmosphere for $12 \mathrm{~h} .{ }^{b}$ Determined by ${ }^{\mathrm{H}} \mathrm{NMR}$. ${ }^{c}$ Determined by chiral GC using CP-Chirasil Dex CB column at $120{ }^{\circ} \mathrm{C}$ (isothermal). ${ }^{\mathrm{d}} \%$ ees obtained with the catalysts prepared from ratio of host/guest is 2,3 , and 4 . ${ }^{e}$ Reactions carried out in $\mathrm{MeOH}$ solvent.
Even though the precise nature of the interaction between achiral host and chiral guest is not clear yet, the hydrogenbonding would be dominated. To evaluate the interaction of the chiral guest to host forming $\mathbf{H} / \mathbf{G}$ complexes, ${ }^{1} \mathrm{H}$ NMR titration was conducted by adding incremental amounts of the $\mathrm{H}-\mathrm{BDPMI}$ to a $0.005 \mathrm{M}$ solution of host 5 in $\mathrm{CD}_{2} \mathrm{Cl}_{2}$ at $23{ }^{\circ} \mathrm{C}$. A remarkable downfield shift $(\Delta \delta=2.04 \mathrm{ppm})$ was observed for the N-H signal $(\delta=9.004 \mathrm{ppm})$ of host 5 . Moreover, the aromatic $\mathrm{C}-\mathrm{H}(\delta=8.629 \mathrm{ppm})$ also slightly shifted to downfield $(\Delta \delta=0.28 \mathrm{ppm})$. The NMR titration data were analyzed
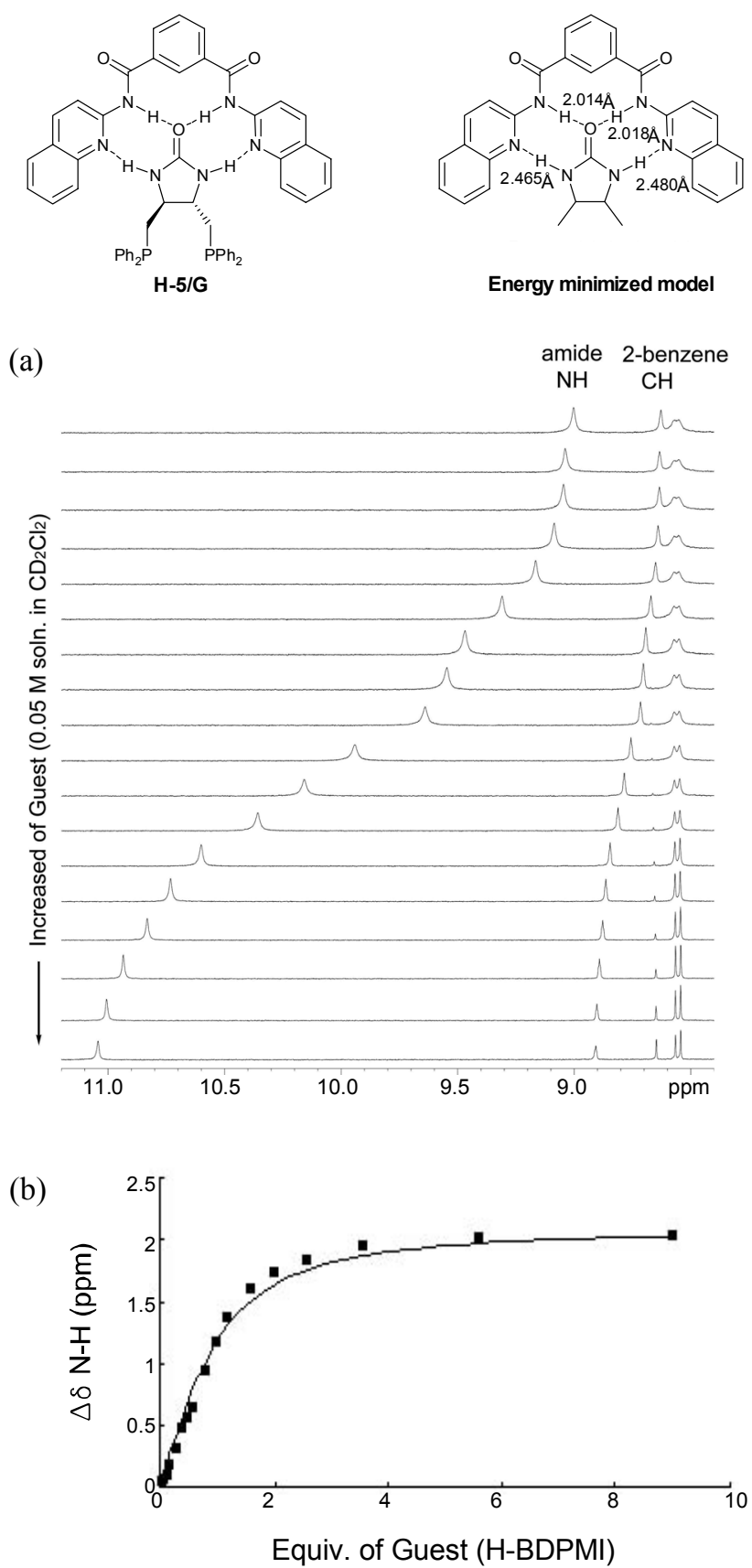

Figure 2. Structures of $\mathbf{H - 5 / G}$ and energy minimized model $H / G$ complex, and (a) ${ }^{1} \mathrm{H}$ NMR titration spectra of the $\mathbf{H - 5}\left(\mathrm{NH}, \mathrm{CH}_{\mathrm{ph}}\right.$, $\mathrm{CH}_{\text {quinoline }}$ resonances are shown) with H-BDPMI guest $(0.0 \sim 10.0$ equivalent). (b) Plot of the observed downfield chemical shifts of the $\mathrm{d}_{\mathrm{N}-\mathrm{H}}$ resonances of $\mathbf{H - 5}$ as a function of added H-BDPMI. 
using a linear least squares fitting procedure similar to that described by Wilcox and Cowart, ${ }^{8}$ and the calculated association constant was $K_{a}=550$. Formation of present host-guest complex via hydrogen bonding was further evidenced by energy minimized conformation of 4,5-dimethylimidazolidin-2-one as a guest. The amide hydrogen atoms were hydrogen-bonded with the carbonyl oxygen of the guest (H---O: $2.014 \AA$ and $2.018 \AA$ ) and quinoline nitrogen atoms were hydrogen- bonded with amide hydrogen of the guest (N---H: $2.465 \AA$ and $2.480 \AA$ ). Based on these results, it could be concluded that there is multiple hydrogen bonding interaction between imidazolidinone moiety of chiral bisphosphine guest and host to form chiral $\mathbf{H} / \mathbf{G}$ complexes.

In summary, we presented a host/guest-based asymmetric catalysis. Although the effects are not so dramatic, it was found that the intermolecular hydrogen-bonding interactions between achiral host and chiral guest affected positively on the enantioselectivity. However, the exact role of the host in the transmission of asymmetry remains to be elucidated. This work set up a stage for further catalyst optimization with structurally diverse achiral host available from combinatorial preparation, and for conceptual design on chiral host and achiral guest, in which the chiral information of the host could be transferred to the reactive site of the metal complex of the achiral guest ligand.

\section{Experimental}

Achiral hosts 1 $\mathbf{5}$ were synthesized by reaction of isophthaloyl dichloride with the corresponding amines, 8-aminoquinoline (H-1), 2-methyl-8-aminoquinoline (H-2) which prepared by hydrogenation of 8-nitroqunaldine, 2-aminopyridine (H-3), 2-amino-6-picoline (H-4), and 2-aminoquinoline (H-5).

An example synthetic procedure for achiral host. A solution of isophthaloyl dichloride $(1.0 \mathrm{~g}, 4.93 \mathrm{mmol})$ in anhydrous benzene $(50 \mathrm{~mL})$ was added dropwise to a suspension of 8 aminoquinoline $(1.5 \mathrm{~g}, 10.04 \mathrm{mmol})$ and triethylamine $(1.4$ $\mathrm{mL}, 10.0 \mathrm{mmol})$ in anhydrous benzene $(20 \mathrm{~mL})$. The mixture was stirred at $75^{\circ} \mathrm{C}$ for $12 \mathrm{~h}$ under nitrogen atmosphere. After benzene was removed from the mixture by evaporation, the residue was dissolved in chloroform and washed with water. The chloroform solution was dried over anhydrous $\mathrm{Na}_{2} \mathrm{SO}_{4}$, filtered and concentrated under reduced pressure.

$\boldsymbol{N}, N^{\prime}$-Bis[(8-quinolyl)carbamoyl]isophthalamide (Host-1). Re-crystallization from benzene. Yield: $92 \%$; White solid (mp $\left.194 \sim 195{ }^{\circ} \mathrm{C}\right) ;{ }^{1} \mathrm{H}$ NMR $\left(400 \mathrm{MHz}, \mathrm{CDCl}_{3}\right) \delta 7.50$ (dd, $J=$ $4.24 \& 4.20 \mathrm{~Hz}, 2 \mathrm{H}, 7$-quinoline protons), 7.57-7.65 (m, 4H, 5,6 -quinoline protons), $7.75(\mathrm{t}, J=7.73 \mathrm{~Hz}, 1 \mathrm{H}$, benzene proton), 8.20 (dd, $J=1.60 \& 1.60 \mathrm{~Hz}, 2 \mathrm{H}, 3$-quinoline protons), 8.30 (dd, $J=1.80 \& 1.80 \mathrm{~Hz}, 2 \mathrm{H}, 4$-quinoline protons), 8.79 (d, $J=1.56 \mathrm{~Hz}, 1 \mathrm{H}$, benzene proton), 8.87 (dd, $J=1.64 \& 1.60$ $\mathrm{Hz}, 2 \mathrm{H}$, benzene protons), 8.97 (dd, $J=1.52 \& 1.52 \mathrm{~Hz}, 2 \mathrm{H}$, 2-quinoline protons), 10.87 (s, $2 \mathrm{H}$, amide $\mathrm{NH}$ protons); ${ }^{13} \mathrm{C}$ NMR (100.6 MHz, $\left.\mathrm{CDCl}_{3}\right) \delta 116.75,121.78,122.01,126.10$, 127.41, 128.00, 129.41, 130.55, 134.39, 135.90, 136.40, 138.78, 148.44, 164.65. Anal. Calcd. for $\mathrm{C}_{26} \mathrm{H}_{18} \mathrm{~N}_{4} \mathrm{O}_{2}$ : C, 74.63; $\mathrm{H}, 4.34$; N, 13.39. Found: C, 74.62; H, 4.29; N, 13.49; HRMS (ES): $m / z$ calcd. for $\mathrm{C}_{26} \mathrm{H}_{18} \mathrm{~N}_{4} \mathrm{O}_{2}:[\mathrm{M}+\mathrm{H}]^{+}=419.1509$, found $=$

\subsection{7.}

$\boldsymbol{N}, N^{\prime}$-Bis [(2-methyl-8-quinolyl)carbamoyl]isophthalamide (Host-2). Re-crystallization from benzene. Yield: 78.5\%; Yellowish solid (mp 245 246 $\left.{ }^{\circ} \mathrm{C}\right) ;{ }^{1} \mathrm{H}$ NMR $\left(400 \mathrm{MHz}, \mathrm{CDCl}_{3}\right) \delta$ $2.74\left(\mathrm{~s}, 6 \mathrm{H}, 2 \mathrm{CH}_{3}\right), 7.35(\mathrm{~d}, J=8.36 \mathrm{~Hz}, 2 \mathrm{H}, 7$ - quinoline protons), 7.51-7.57 (m, 4H, 5,6-quinoline protons), 7.76 (t, $J=7.72$ $\mathrm{Hz}, 1 \mathrm{H}$, benzene proton), 8.07 (d, $J=8.36 \mathrm{~Hz}, 2 \mathrm{H}, 3$-quinoline protons), 8.29 (dd, $J=1.80 \& 1.80 \mathrm{~Hz}, 2 \mathrm{H}, 4$-quinoline protons), 8.82 (t, $J=1.64 \mathrm{~Hz}, 1 \mathrm{H}$, benzene proton), 8.91 (dd, $J=$ $2.32 \& 2.32 \mathrm{~Hz}, 2 \mathrm{H}$, benzene protons), 10.95 (s, 2H, amide $\mathrm{NH}$ protons $) ;{ }^{13} \mathrm{C} \mathrm{NMR}\left(100.6 \mathrm{MHz}, \mathrm{CDCl}_{3}\right) \delta 25.41,116.69$, $121.73,122.55,126.10,122.16,126.36,129.39,130.35$, 133.76, 136.06, 136.48, 138.15, 157.47, 164.46; Anal. Calcd. for $\mathrm{C}_{28} \mathrm{H}_{22} \mathrm{~N}_{4} \mathrm{O}_{2}$ : C, 75.32; H, 4.97; N, 12.55. Found: C, 75.37; $\mathrm{H}, 4.77$; N, 12.37; HRMS (ES): $m / z$ calcd. for $\mathrm{C}_{28} \mathrm{H}_{22} \mathrm{~N}_{4} \mathrm{O}_{2}$ : $[\mathrm{M}+\mathrm{H}]^{+}=447.1822$, found $=447.1824$.

1,3-Bis [\{ (pyridine-2-yl)amino\} carbonyl]benzene (Host-3). Re-crystallization from ethanol. Yield: 64\%; White solid (mp $177 \sim 178{ }^{\circ} \mathrm{C}$ ); ${ }^{1} \mathrm{H} \mathrm{NMR}\left(400 \mathrm{MHz}, \mathrm{CDCl}_{3}\right) \delta 7.09$ (q, $J=7.18$ $\mathrm{Hz}, 2 \mathrm{H}, 5$-pyridine protons), $7.65(\mathrm{t}, J=7.75 \mathrm{~Hz}, 1 \mathrm{H}$, benzene proton), 7.76-7.80 (m, 2H, 4-pyridine protons), 8.15 (dd, $J=$ $1.60 \& 1.56 \mathrm{~Hz}, 2 \mathrm{H}$, benzene protons), $8.28(\mathrm{~d}, J=4.10 \mathrm{~Hz}$, $2 \mathrm{H}, 6$-pyridine protons), 8.39 (d, $J=8.34 \mathrm{~Hz}, 2 \mathrm{H}, 3$-pyridine protons), $8.56(\mathrm{~s}, 1 \mathrm{H}$, benzene proton $), 8.95(\mathrm{~s}, 2 \mathrm{H}$, amide $\mathrm{NH}$ protons); ${ }^{13} \mathrm{C}$ NMR (100.6 $\left.\mathrm{MHz}, \mathrm{CDCl}_{3}\right) \delta 114.30,120.19$, 126.04, 129.51, 130.88, 134.94, 138.57, 147.91, 151.34, 164.60; Anal. Calcd. for $\mathrm{C}_{18} \mathrm{H}_{14} \mathrm{~N}_{4} \mathrm{O}_{2}$ : C, 67.91; H, 4.43; N, 17.60. Found: C, 65.07; H, 4.50; N, 18.41; HRMS (ES): $m / z$ calcd. for $\mathrm{C}_{18} \mathrm{H}_{14} \mathrm{~N}_{4} \mathrm{O}_{2}:[\mathrm{M}+\mathrm{H}]^{+}=319.1196$, found $=319.1196$

1,3-Bis [ ( 6-methyl-pyridine-2-yl)amino\} carbonyl]benzene (Host-4). Crystallization from ethyl acetate and $n$-hexane. Yield: 76\%; White solid (mp $143 \sim 144{ }^{\circ} \mathrm{C}$ ); ${ }^{1} \mathrm{H}$ NMR $(400 \mathrm{MHz}$, $\left.\mathrm{CDCl}_{3}\right) \delta 2.47\left(\mathrm{~s}, 6 \mathrm{H}, 2 \mathrm{CH}_{3}\right), 6.95(\mathrm{~d}, J=7.46 \mathrm{~Hz}, 2 \mathrm{H}, 5$-pyridine protons), 7.63 (t, $J=7.78 \mathrm{~Hz}, 1 \mathrm{H}$, benzene proton), $7.66(\mathrm{t}, J=$ $7.87 \mathrm{~Hz}, 2 \mathrm{H}, 4$-pyridine protons), 8.13 (dd, $J=1.80 \& 1.80 \mathrm{~Hz}$, $2 \mathrm{H}$, benzene protons), 8.18 (d, $J=8.24 \mathrm{~Hz}, 2 \mathrm{H}, 3$-pyridine protons), 8.51 ( $\mathrm{t}, J=1.64 \mathrm{~Hz}, 1 \mathrm{H}$, benzene proton), $8.70(\mathrm{~s}, 2 \mathrm{H}$, amide $\mathrm{NH}$ protons); ${ }^{13} \mathrm{C}$ NMR $\left(100.6 \mathrm{MHz}, \mathrm{CDCl}_{3}\right) \delta 23.98$, $110.99,119.69,125.84,129.44,130.76,135.03,138.79,150.54$, 157.03, 164.44; Anal. Calcd. for $\mathrm{C}_{20} \mathrm{H}_{18} \mathrm{~N}_{4} \mathrm{O}_{2}$ : C, 69.35; $\mathrm{H}$, 5.24; N, 16.17. Found: C, 69.34; H, 5.47; N, 16.25: HRMS (ES): $m / z$ calcd. for $\mathrm{C}_{20} \mathrm{H}_{18} \mathrm{~N}_{4} \mathrm{O}_{2}:[\mathrm{M}+\mathrm{H}]^{+}=347.1509$, found $=$ 347.1503 .

$\boldsymbol{N}, \boldsymbol{N}^{\prime}$-Bis [(2-quinolyl)carbamoyl]isophthalamide (Host-5). Re-crystallization from benzene. Yield: $65 \%$; White solid (mp $\left.215 \sim 216{ }^{\circ} \mathrm{C}\right) ;{ }^{1} \mathrm{H} \mathrm{NMR}\left(400 \mathrm{MHz}, \mathrm{CDCl}_{3}\right) \delta 7.47-7.51(\mathrm{~m}, 2 \mathrm{H}$, 3-quinoline protons), 7.70 (dd, $J=1.08 \& 1.01 \mathrm{~Hz}, 2 \mathrm{H}, 6$-quinoline protons), $7.70(\mathrm{t}, J=1.46 \mathrm{~Hz}, 1 \mathrm{H}$, benzene proton), 7.83 (dd, $J=0.82 \& 0.84 \mathrm{~Hz}, 2 \mathrm{H}, 7$-quinoline protons), 7.86 (d, $J=$ $8.53 \mathrm{~Hz}, 2 \mathrm{H}, 8$-quinoline protons), 8.22 (dd, $J=1.41 \& 1.40$ $\mathrm{Hz}, 2 \mathrm{H}, 5$-quinoline protons), $8.26(\mathrm{~d}, J=8.99 \mathrm{~Hz}, 2 \mathrm{H}$, benzene protons), 8.57 (bs, $2 \mathrm{H}, 4$-quinoline protons), 8.64 (s, $1 \mathrm{H}$, benzene proton), 8.95 (s, $2 \mathrm{H}$, amide $\mathrm{NH}$ protons); ${ }^{13} \mathrm{C}$ NMR (100.6 $\left.\mathrm{MHz} \mathrm{CDCl}_{3}\right) \delta 114.38,125.44,126.27,126.52,127.39,127.64$, 129.58, 130.19, 131.08, 135.06, 138.85; Anal. Calcd. for $\mathrm{C}_{26}$ $\mathrm{H}_{18} \mathrm{~N}_{4} \mathrm{O}_{2}$ : C, 74.63; H, 4.34; N, 13.39. Found: C, 74.73; H, 4.18; $\mathrm{N}, 13.17$; HRMS (ES): $m / z$ calcd. for $\mathrm{C}_{26} \mathrm{H}_{18} \mathrm{~N}_{4} \mathrm{O}_{2}:[\mathrm{M}+\mathrm{H}]^{+}=$ 419.1509 , found $=419.1508$. 
General procedure for the asymmetric hydrogenation of $\mathrm{N}$ acetyl-1-phenylethenamide. In an argon-filled glovebox, a reaction flask was charged with $\left[\mathrm{Rh}(\operatorname{cod})_{2}\right] \mathrm{BF}_{4}\left(6.2 \times 10^{-3} \mathrm{mmol}\right)$ and H-BDPMI $\left(6.2 \times 10^{-3} \mathrm{mmol}\right)$ in $2.0 \mathrm{~mL}$ of solvent, and the mixture was stirred for $1 \mathrm{~h}$ at room temperature. Then, the host $\left(6.2 \times 10^{-3} \mathrm{mmol}\right)$ was added to the reaction mixture and stirred for additional $2 \mathrm{~h}$ at the same temperature. $N$-Acetyl-1-phenylethenamide (100 mg, $0.62 \mathrm{mmol})$ was added to the reaction mixture, and then hydrogenation performed under $1 \mathrm{~atm}$ of $\mathrm{H}_{2}$ pressure for $12 \mathrm{~h}$. The reaction mixture was passed through a short silica gel column to remove the catalyst. After evaporation of the solvent, the crude reaction mixture was subjected into the ${ }^{1} \mathrm{H}$ NMR and capillary GC to determine the conversion and enantiomeric excess, respectively.

Detemination of enantiomeric excess. Chiral Capillary GC column: CP-Chiralsil-Dex-CB column (dimension $30 \mathrm{~m} \times 0.32$ $\mathrm{mm}$ (i.d.)); Carrier gas: $\mathrm{N}_{2}(1.8 \mathrm{~mL} / \mathrm{min}) ; 120^{\circ} \mathrm{C}$, isothermal; retention time: $(S)$-isomer $=29.37 \mathrm{~min},(R)$-isomer $=33.06 \mathrm{~min}$.

Ka calculation. Energy-minimized structure was obtained from MacroModel 7.1 program on a Silicon Graphics Indigo IMPACT workstation. ${ }^{9}$ The structure was generated with MM2* force field via 3000 separated search steps in Monte Carlo conformational search. A least square fitting program was used to calculate $\mathrm{Ka}$ according to an adaptation of the method of Wilcox and Cowart. ${ }^{8}$ The expression involved was:

$$
\begin{aligned}
\delta_{\text {obs }}= & \left(\delta_{\text {inf }}-\delta_{0}\right)\left[\left\{\left(1+[\mathrm{G}] /[\mathrm{H}]+1 / \mathrm{K}_{\mathrm{a}}[\mathrm{H}]\right) / 2\right\}\right. \\
& \left.\left.-\sqrt{\left[\left(1+[\mathrm{G}] /[\mathrm{H}]+1 /(\mathrm{Ka}[\mathrm{H}])^{2} / 4[\mathrm{G}] /[\mathrm{H}]\right.\right.}\right)\right]+\delta_{0}
\end{aligned}
$$

Where

$$
\begin{aligned}
& {[\mathrm{H}]=\text { conc. of host }} \\
& {[\mathrm{G}]=\text { conc. of guest }}
\end{aligned}
$$

$$
\begin{aligned}
& \delta_{\text {obs }}=\delta_{\mathrm{N}-\mathrm{H}} \text { of pure host } \\
& \delta_{\text {inf }}=\delta_{\mathrm{N}-\mathrm{H}} \text { of complex (calaulated) }
\end{aligned}
$$

Acknowledgments. This work was supported by the grants from Korea Research Foundation (KRF-2006-312-C00587), and from the National Research Foundation of Korea through the Basic Research Program (No. 20090070898 and No. 2009 0063004).

\section{References}

1. Noyori, R. Asymmetric Catalysis in Organic Synthesis; Wiley: New York, 1994; Comprehensive Asymmetric Catalysis; Jacobson, E. N.; Pfaltz, A.; Yamamoto, H., Eds.; Springer: Berlin, 1999; Vol. 1-3; Catalytic Asymmetric Synthesis, 2nd ed.; Ojima, I., Ed.: Wiley-VCH: New York, 2000.

2. Walsh, P. J.; Lurain, A. E.; Balsells, J. Chem. Rev. 2003, 103, 3297.

3. Roelfes, G.; Feringa, B. L. Angew. Chem. Int. Ed. 2005, 44, 3230.

4. Lee, S.-g.; Zhang, Y. J.; Song, C. E.; Lee, J. K.; Choi, C. H. Angew. Chem. Int. Ed. 2002, 41, 847.

5. Bell, D. A.; Anslyn, E. V. Hydrogen-bonding Receptors: Openchain Catalytic System in Comprehensive Supramolecular Chemistry; Lehn, J.-M., ed.: Pergamon Elsevier Science: 1996; Vol. 2, Chapter 14, pp. 439-475.

6. Mazik, M.; Radunz, W.; Boese, R. J. Org. Chem. 2004, 69, 7448.

7. (a) Hedge, V.; Hung, C.-Y.; Madhukar, P.; Cunningham, R.; Höphner, T.; Thummel, R. P. J. Am. Chem. Soc. 1993, 115, 872. (b) Fielding, L. Tetrahedron 2000, 56, 6151.

8. Cowart, M. D.; Sucholeiki, I.; Bukownik, R. R.; Wilcox, C. S. J. Am. Chem. Soc. 1988, 110, 6204.

9. (a) Mohamedi, F.; Richards, N. G. T.; Liskamp, W. C. H.; Lipton, M.; Caufield, C.; Chang, G.; Hendrickson, T.; Still, W. C. J. Comp. Chem. 1990, 11, 440. (b) Allinger, N. L.; Yuh, Y. QCPE 1980, 12, 395. (b) Burker, U.; Allinger, N. L. Molecular Mechanics; American Chemical Society: Washington, DC, 1982. (c) Saunders, M.; Houk, K. N.; Wu, Y. D.; Still, W. C.; Lipton, M.; Chang, G.; Guida, W. C. J. Am. Chem. Soc. 1990, 112, 1419. 